\title{
Nitrogen excretion and absorption efficiencies of sardine Sardinops sagax fed phytoplankton and zooplankton diets
}

\author{
C. D. van der Lingen* \\ Sea Fisheries Research Institute, Private Bag X2, Rogge Bay 8012, South Africa
}

\begin{abstract}
Laboratory experiments to measure nitrogen excretion rates and estimate absorption efficiencies were conducted on adult sardine Sardinops sagax fed phytoplankton and zooplankton diets. Sardine are predominantly ammoniotelic, with an endogenous total nitrogen excretion rate of $28.11 \pm$ $1.90 \mu \mathrm{g} \mathrm{N} \mathrm{g} \mathrm{g}^{-1} \mathrm{DBM}$ (dry body mass) $\mathrm{h}^{-1}$. Neither fish size nor temperature had a significant effect on endogenous excretion rates. Peak post-feeding exogenous nitrogen excretion rates were 3.5 to 10 times higher than endogenous rates, were linearly related to nitrogen ration, and occurred within $3 \mathrm{~h}$ of the ingestion of food. Absorption of a meal was rapid; $50 \%$ of the exogenous nitrogen was excreted by 2.2 $\pm 1.0 \mathrm{~h}$ and $90 \%$ by $7.4 \pm 3.6 \mathrm{~h}$. Faeces elimination was exponential and dependent on food type; phytoplankton was eliminated faster than zooplankton. Elimination of the meal was much slower than the excretion of dissolved nitrogen, requiring $13.0 \pm 4.1 \mathrm{~h}$ for $50 \%$ elimination and $50.8 \pm 8.3 \mathrm{~h}$ for $90 \%$ elimination. Faeces C:N ratios decreased over time for fish fed phytoplankton, but increased when zooplankton was the food. A constant portion of the ingested and absorbed nitrogen was excreted (69.8 \pm 11.1 and $74.4 \pm 12.1 \%$ respectively), and it is estimated that adult sardine require an absorbed daily maintenance ration of $2.64 \mathrm{mg} \mathrm{N} \mathrm{g}^{-1} \mathrm{DBM} \mathrm{d} \mathrm{d}^{-1}$ Sardine are omnivorous, but have higher absorption efficiencies when fed zooplankton $(77.6,88.2$ and $93.3 \%$ for dry mass, carbon and nitrogen respectively) than when fed phytoplankton $(42.6,62.6$ and $78.7 \%)$. That Sardinops sagax is able to better utilize zooplankton than phytoplankton suggests that this species derives more of its nutritional requirements from carnivory than from herbivory.
\end{abstract}

KEY WORDS: Sardinops sagax . Planktivorous fish · Nitrogen excretion . Absorption efficiency · Phytoplankton - Zooplankton

\section{INTRODUCTION}

Sardine Sardinops sagax is a major component of landings by pelagic fisheries in upwelling regions of the world and, together with anchovy Engraulis spp., frequently dominates world fishery production (FAO 1997). The success of sardine and anchovy in upwelling regions was initially attributed to their ability to feed directly upon phytoplankton (Ryther 1969), and therefore to harness the high productivity of these systems through an efficient, 2-level food chain. However,

·E-mail: vdlingen@sfri.wcape.gov.za recent studies have suggested that most clupeoids are omnivorous and derive the bulk of their energy intake from zooplankton (Koslow 1981, James 1987, James 1988).

Sardine is predominantly a filter-feeding species which is able to capture food particles down to $17 \mu \mathrm{m}$ in size (van der Lingen 1994), and which maximizes its energy gain through prolonged bouts of energetically cheap filtering (van der Lingen 1995). Sardine stomachs typically contain both phytoplankton and zooplankton prey (Davies 1957, King \& Macleod 1976, van der Lingen 1996), and the minimal diel variation in stomach content mass suggests that these fish filterfeed almost continuously (van der Lingen 1998). 
Sardinops sagax is therefore morphologically and behaviorally well equipped to utilize both phytoplankton and zooplankton as food sources.

This paper describes the nitrogen excretion, and absorption efficiencies in terms of dry mass, carbon, and nitrogen, of sardine fed phytoplankton and zooplankton diets. These data are required for the construction of carbon and nitrogen budgets for Sardinops sagax. The methodology employed here follows that used by Durbin \& Durbin (1981) and James et al. (1989a) to examine the absorption efficiencies of Atlantic menhaden Brevoortia tyrannus and Cape anchovy Engraulis capensis respectively, and therefore permits detailed comparisons between these clupeoid species.

\section{MATERIAL AND METHODS}

Laboratory populations of sardine were collected and maintained as described by van der Lingen (1994). Two size classes of adult sardine were used in experiments: large adults were $252.8 \pm 19.0 \mathrm{~mm}$ total length (TL), $136.4 \pm 30.7 \mathrm{~g}$ wet body mass (WBM), and $46.8 \pm$ $14.5 \mathrm{~g}$ dry body mass (DBM), and small adults were $205.0 \pm 11.3 \mathrm{~mm} \mathrm{TL}, 64.2 \pm 12.5 \mathrm{~g} \mathrm{WBM}$, and $17.6 \pm$ $3.8 \mathrm{~g}$ DBM (Table 1). Experiments to measure endogenous excretion rates of both ammonia and urea, and experiments where fish were fed either phytoplankton or zooplankton diets, were conducted on both groups (Table 1). Fish were deprived of food for 2 to $5 \mathrm{~d}$ prior to use in all experiments.

Experiments were conducted in $2.0 \mathrm{~m}$ diameter, 2670 l capacity fibreglass tanks subject to the ambient light regime. During experiments to determine endogenous ammonia and urea excretion rates, water samples were collected every 3 h over periods of 1 to $4 \mathrm{~d}$ during which the fish were not fed. Experiments during which the fish were fed began with measurements of endogenous ammonia and urea production over 3 to $24 \mathrm{~h}$, after which food was added to the tank. Water and faeces samples were then collected regularly, initially every hour for a 6 to $12 \mathrm{~h}$ period, and then with decreasing frequency over periods of 2 to $6 \mathrm{~d}$ after the introduction of food. Three of the experiments in which phytoplankton was offered as food used natural assemblages (primarily Chaetoceros spp.) collected from coastal waters with a drift net of $37 \mu \mathrm{m}$ mesh; in the fourth experiment the benthic diatom Melosira spp. was collected from the sand filters of the aquarium facility (Table 1). Natural assemblages of zooplankton used in the experiments consisted primarily of copepods which were collected using a drift net of $200 \mu \mathrm{m}$ mesh. The species composition, ration size, and carbon and nitrogen content of food used in experiments was determined from subsamples (Table 1).

Prior to experimentation, the tanks were thoroughly cleaned and flushed with $5 \mu \mathrm{m}$ filtered sea water at ambient temperature. The water volume in the tank was reduced to 1000 l. in order to facilitate high food concentrations and ensure a good feeding response. The addition of food to the experimental tank elicited a strong feeding response in all experiments, with fish increasing their swimming speed and feeding by either filtering or biting, depending on food type. As food concentrations declined, both swimming speed and the proportion of the shoal feeding decreased. Feeding was considered to have stopped when less than $10 \%$ of the shoal was feeding, and at this time uneaten food which had settled onto the bottom of the tank was removed. The water volume in the tank was then increased to $2670 \mathrm{l}$ using $5 \mu \mathrm{m}$ filtered sea water at ambient temperature. It was assumed that all food not removed from the tank at the end of the feeding period had been consumed.

Sea water was not supplied to the tanks after the termination of feeding, and this resulted in a gradual increase in water temperature over the experimental period. When necessary, the tanks were flushed in order to reduce water temperatures. The increase in temperature during experiments in which the fish were not fed permitted an assessment of the effect of temperature on endogenous excretion rates, and as this was done for both groups of experimental fish, allowed a comparison of endogenous excretion rates for fish of different size.

Water samples were collected using a $100 \mathrm{ml}$ syringe, and were filtered through pre-rinsed Whatman GF/F filters into a clean beaker. All glassware was acid washed. Triplicate $5 \mathrm{ml}$. subsamples for ammonia and urea analysis were stored in clean borosilicate test tubes at $-20^{\circ} \mathrm{C}$ until processed. Ammonia and urea concentrations were determined following the methods described by Koroleff (1983), scaled down to a $5 \mathrm{ml}$ sample volume. All determinations were carried out in triplicate

Faeces were collected through siphoning into a clean 201 bucket, and the water removed from the tank was returned by back-filtration through a $63 \mu \mathrm{m}$ mesh. Collected faeces were rinsed in distilled water, concentrated onto pre-weighed Whatman GF/F filter papers through filtration under a low vacuum, and dried for 24 h at $60^{\circ} \mathrm{C}$. Faeces dry mass was determined to the nearest $0.1 \mathrm{mg}$ using a Sartorius 2462 electrobalance, and the carbon and nitrogen content of each faeces sample was determined using a Leco CHNS 932 analyser. Dry mass, carbon and nitrogen absorption efficiencies were calculated from the total amounts of each. constituent in the faeces and that 
Table 1. Sardinops sagax. Summary of information for laboratory experiments on absorption efficiency of sardine. The starvation time, temperature range, food type, ration size, feeding duration, carbon and nitrogen content of the food, food C:N ratio, and samples collected are listed for each experiment. LA: experiments conducted on large adult fish; SA: experiments conducted on small adult fish. The mean carbon and nitrogen content and mean $\mathrm{C}: \mathrm{N}$ ratio of 5 small adult sardine is also given

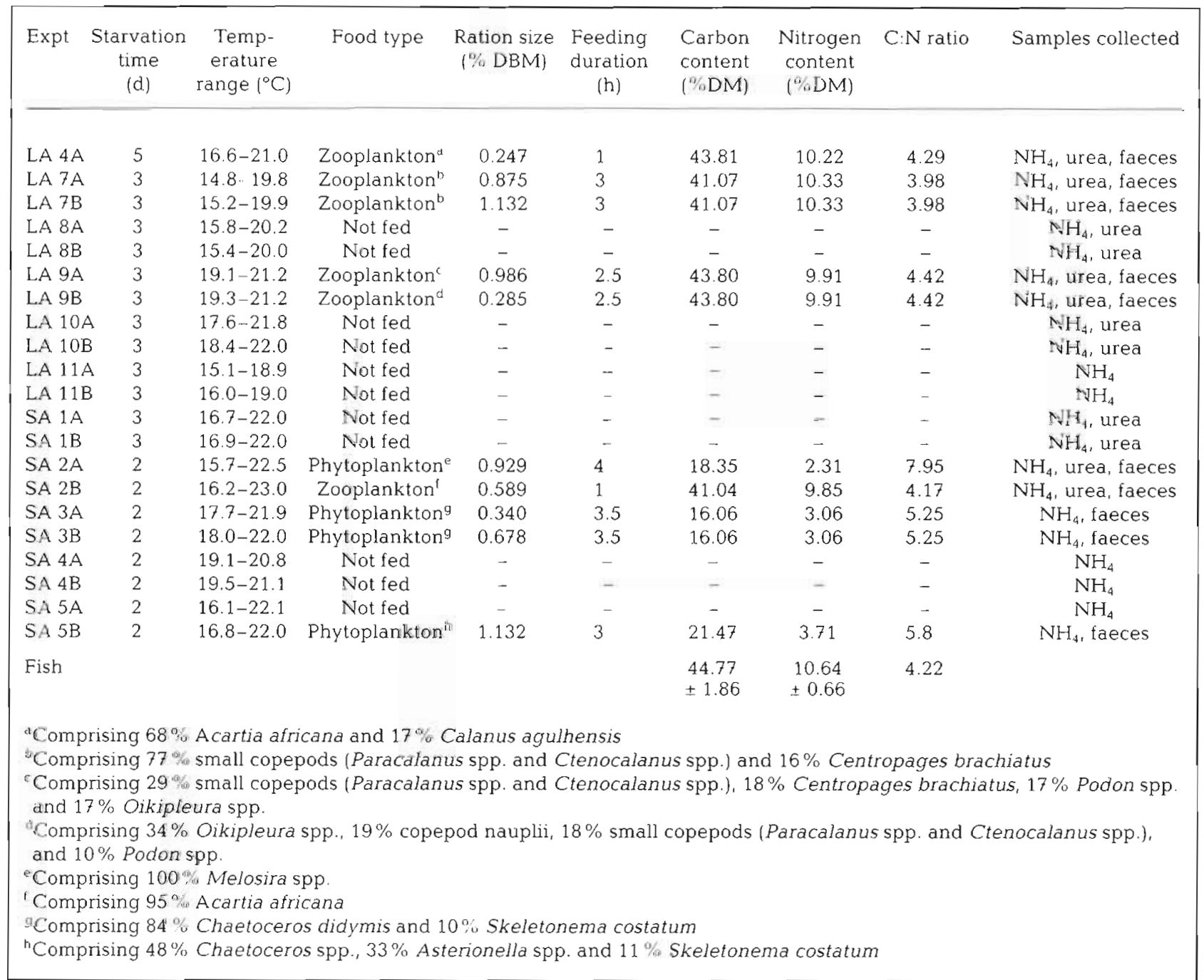

available in the food using the following expression:

$$
\begin{aligned}
& \% \text { absorption efficiency }= \\
& \frac{\text { component }_{\text {tood }}-\text { component }_{\text {faeces }} \times 100}{\text { component }_{\text {food }}}
\end{aligned}
$$

Experiments to determine the relative contribution of ammonia to the total nitrogen excreted by sardine were conducted in a $3 \mathrm{~m}^{3}$ glass display tank containing approximately 300 subadult sardine of 30 to $40 \mathrm{~g}$ WBM. One experiment was performed on unfed fish, and a second was done on fish which had been fed mysids Mysodopsis major. Water samples were collected every $15 \mathrm{~min}$ and were analysed for ammonia using the methods described above. Total dissolved organic nitrogen (T-DON) was determined using the method of Nydahl (1978). Because the total mass of sardine in the tank was not determined, absolute total nitrogen and ammonia excretion rates could not be calculated. The relative contribution made by ammonia to the total nitrogen excreted was estimated by regressing ammonia and T-DON concentrations against time, and dividing the T-DON slope value by the ammonia slope value.

\section{RESULTS}

\section{Endogenous ammonia and urea excretion}

Large-scale changes in ammonia concentrations in the experimental tanks meant that its excretion rate 


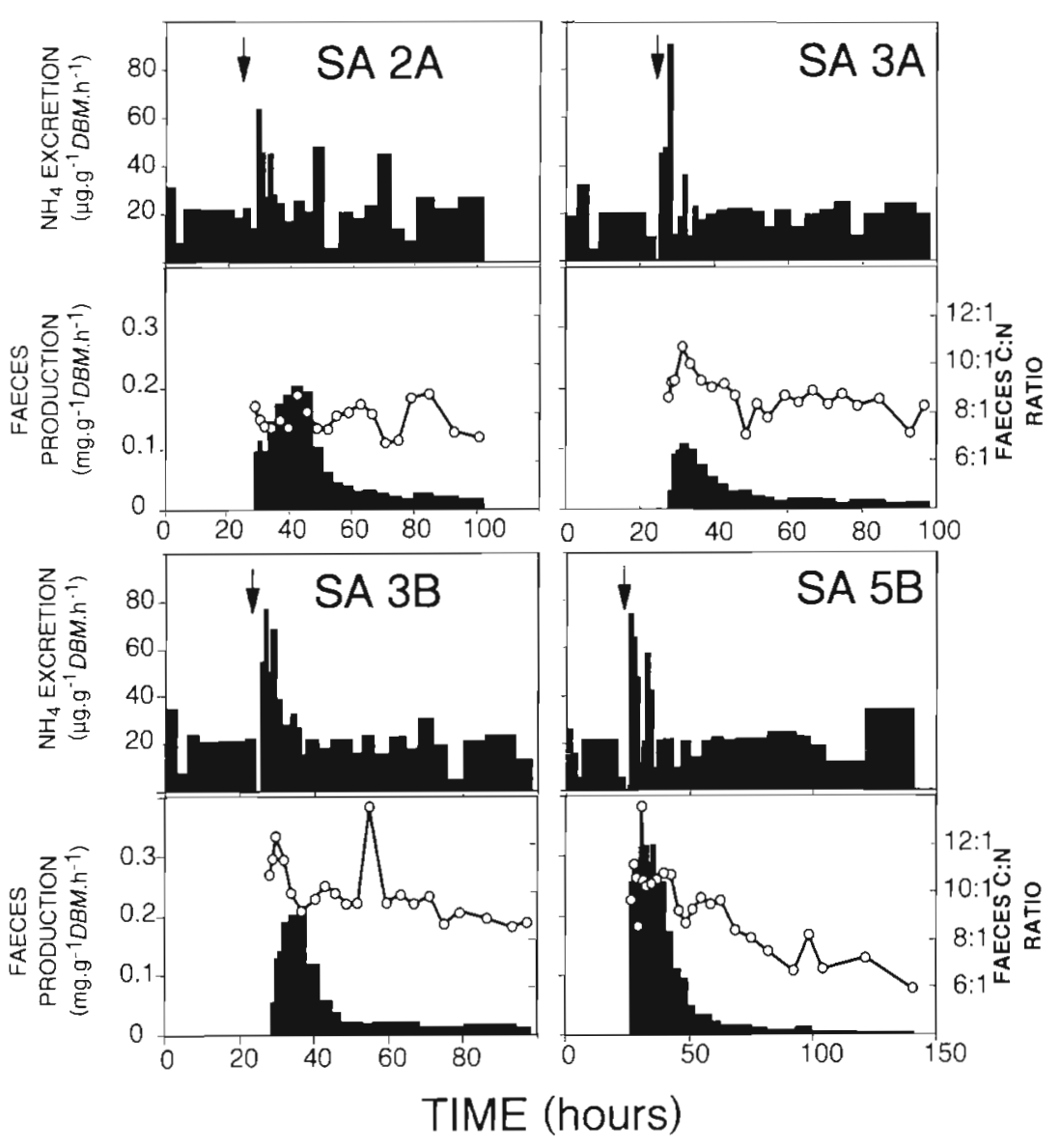

Fig. 1. Ammonia excretion rate (histogram; $\mu \mathrm{g} \mathrm{N} \mathrm{g}^{-1} \mathrm{DBM} \mathrm{h}{ }^{-1}$ ), faeces production rate (histogram; mg dry mass $\mathrm{g}^{-1} \mathrm{DBM} \mathrm{h}^{-1}$ ) and faeces $\mathrm{C}: \mathrm{N}$ ratio (O and line) during experiments in which Sardinops sagax was fed phytoplankton. Arrows indicate the initiation of feeding mean value $( \pm 95 \% \mathrm{CL})$ of $2.46 \pm 0.87$ $\mu \mathrm{g} \mathrm{Ng}^{-1} \mathrm{DBM} \mathrm{h}^{-1}$.

Significant $(p<0.05)$ regressions between ammonia concentration and time, and between T-DON concentration and time were obtained from both experiments to determine the relative contribution of ammonia to total nitrogen excretion. Ammonia constituted $68.6 \%$ of the total nitrogen excreted by unfed fish, and $75.3 \%$ for fish fed mysids. The mean. endogenous ammonia excretion rate of $19.28 \pm 1.30 \mu \mathrm{g} \mathrm{N} \mathrm{g} \mathrm{NBM} \mathrm{h}^{-1}$ is therefore equivalent to a total nitrogen excretion rate of $28.11 \pm 1.90 \mu \mathrm{g}$ $\mathrm{N}^{-1}$ DBM $\mathrm{h}^{-1}$. The total nitrogen: ammonia ratio of 1.328 determined for fish which had been fed mysids was used to estimate the total nitrogen excretion for all experiments during which the fish were fed.

\section{Exogenous nitrogen excretion}

Exogenous nitrogen excretion was calculated by subtracting the endogenous nitrogen excretion (28.11 $\mu \mathrm{g} \mathrm{N}$ $\mathrm{g}^{-1} \mathrm{DBM} \mathrm{h} \mathrm{h}^{-1}$ ) from the total nitrogen excretion (ammonia excretion multiplied by 1.328 ) during the period of elevated excretion following feeding. Elevated excretion was defined as the period during which excretion levels between subsequent samples could be accurately determined. No statistically significant relationship between endogenous ammonia excretion rate and temperature (range $=15.2$ to $22.1^{\circ} \mathrm{C}$ ) was observed for fish in either of the experimental groups. A 2 -sample $t$-test to compare endogenous ammonia excretion rate across the temperature range for each group indicated no significant difference between groups $(t<0.001)$. The data for both groups were therefore combined, giving a mean endogenous ammonia excretion rate $\pm 95 \% \mathrm{CL}$ of $19.28 \pm 1.30 \mu \mathrm{g} \mathrm{Ng}^{-1} \mathrm{DBM} \mathrm{h}^{-1}$ at a mean temperature of $19.1^{\circ} \mathrm{C}$.

Owing to the high variability in the urea data, less confidence could be placed in the estimation of urea excretion rates. Endogenous urea excretion rate was determined by regressing urea concentration in the tank (expressed as $\mu \mathrm{g}$ urea $\mathrm{g}^{-1}$ DBM) against time, and using the slope parameter of significant regressions to estimate excretion rate. Estimated endogenous urea excretion rates ranged from 1.06 to 3.33 and had a exceeded the upper $95 \%$ confidence limit of the endogenous rate.

Ammonia excretion rates followed a similar pattern in all experiments where fish were fed, increasing above endogenous levels within $1 \mathrm{~h}$ after the introduction of food, reaching a peak level, and declining thereafter. For fish fed phytoplankton, peak ammonia excretion rates of 60 to $90 \mathrm{~kg} \mathrm{~N} \mathrm{~g}^{-1}$ DBM h-1 occurred 1.5 to 5.0 (mean $=2.9 \pm 1.5)$ h after the initiation of feeding (Fig. 1). Excretion rates returned to endogenous levels 4.5 to 13.0 (mean $=9.1 \pm 3.5) \mathrm{h}$ after the initiation of feeding Ammonia excretion rates for fish fed zooplankton were higher and peaked sooner after the initiation of feeding than those in experiments where phytoplankton was the food. Peak excretion rates of fish fed zooplankton were observed 0.5 to 3.0 (mean = $1.6 \pm 0.9) \mathrm{h}$ after the initiation of feeding and ranged from 45 to $195 \mu \mathrm{g} \mathrm{N} \mathrm{g}^{-1} \mathrm{DBM} \mathrm{h}^{-1}$ (Fig 2) Excretion rates returned to endogenous levels 2.5 to 20.0 (mean = $10.9 \pm 6.1$ ) h after the initiation of feeding. 

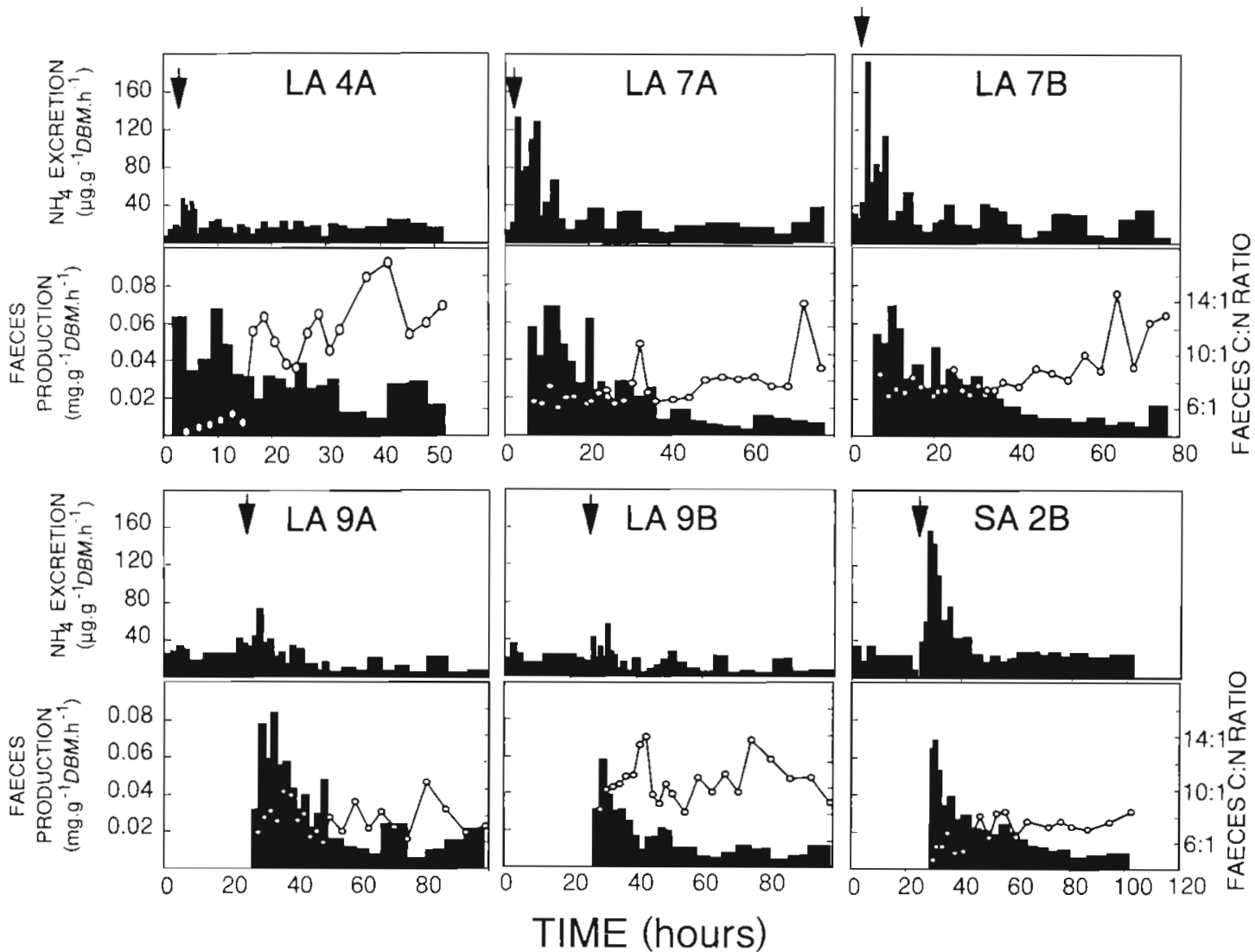

Fig. 2. Ammonia excretion rate (histogram; $\mu \mathrm{g} \mathrm{Ng}^{-1} \mathrm{DBM} \mathrm{h}^{-1}$ ), faeces production rate (histogram; $\mathrm{mg}_{\mathrm{dry}} \mathrm{mass}^{-1} \mathrm{DBM} \mathrm{h}^{-1}$ ) and faeces C: $N$ ratio ( $O$ and line) during experiments in which Sardinops sagax was fed zooplankton. Arrows indicate the initiation of feeding

Despite differences in the timing and levels of peak ammonia excretion rates between fish fed phytoplankton and zooplankton, food type had no effect ( $t$-test; $\mathrm{p}<$

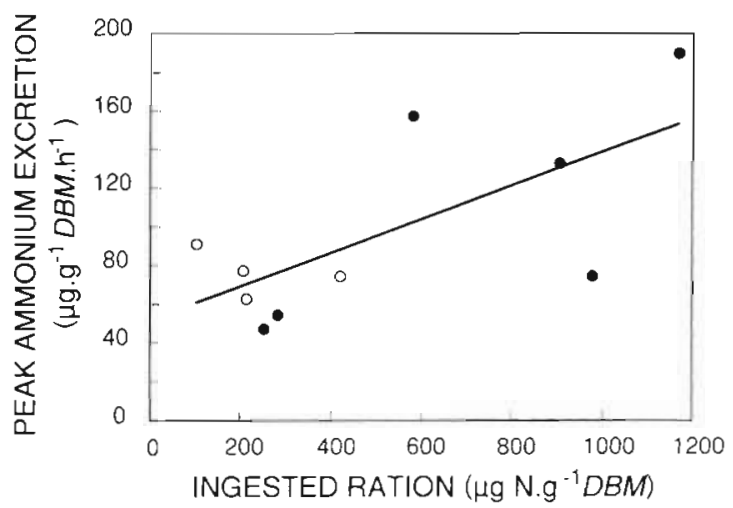

Fig. 3. Relationship between peak ammonium excretion rate after feeding ( $\mu \mathrm{N} \mathrm{g} \mathrm{g}^{-1} \mathrm{DBM} \mathrm{h}^{-1}$ ) and ingested nitrogen ration ( $\mu \mathrm{g} \mathrm{N} \mathrm{g}^{-1} \mathrm{DBM}$ ) for Sardinops sagax. Data from experiments in which phytoplankton was used as food are indicated by an open circle (0) and those from experiments with zooplankton are indicated by a closed circle ( $\bullet$. A linear regression is fitted to the data
0.05) on the times required for 50 and $90 \%$ exogenous nitrogen excretion respectively. The time required for $50 \%$ of the exogenous nitrogen excretion was $2.2 \pm$ $1.0 \mathrm{~h}$ after the mid-point of feeding, and that required for $90 \%$ of the exogenous nitrogen excretion was $7.4 \pm$ $3.6 \mathrm{~h}$. A significant, linear relationship between peak ammonia excretion rate and nitrogen ration was observed (Fig. 3), and had the form:

$$
y=0.088 x+51.3\left(n=10 ; r^{2}=0.40 ; p<0.05\right)
$$

where $y$ is peak ammonia excretion rate in $\mu \mathrm{g} \mathrm{N} \mathrm{g}^{-1}$ $\mathrm{DBM} \mathrm{h} \mathrm{h}^{-1}$ and $\mathrm{x}$ is ingested ration size ( $\left.\mu \mathrm{g} \mathrm{N} \mathrm{g}^{-1} \mathrm{DBM}\right)$.

Significant relationships were also observed between the total exogenous nitrogen excretion (e $e_{\mathrm{N}} \mathrm{mg} \mathrm{N}^{-1} \mathrm{DBM}$ ) and the total nitrogen in both the ingested $\left(R_{\mathrm{N}} ; \mathrm{mg} \mathrm{N} \mathrm{g}{ }^{-1}\right.$ $\mathrm{DBM}$ ) and the absorbed ( $p R_{N} ; \operatorname{mg} \mathrm{N}^{-1} \mathrm{DBM}$ ) rations (Fig. 4). These regressions were forced through the origin to ensure that they adhered to theoretical considerations, namely that zero ingestion results in zero exogenous excretion. The least squares linear regressions were:

$e_{N}=0.698 \pm 0.111 R_{N}\left(n=10 ; r^{2}=0.48 ; p<0.03\right)$
$e_{N}=0.744 \pm 0.121 p R_{N}\left(n=10 ; r^{2}=0.45 ; p<0.03\right)$ 


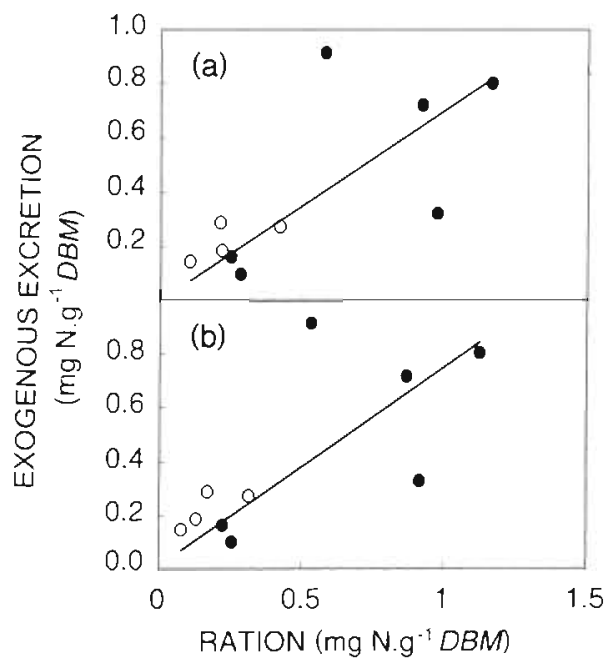

Fig. 4. Relationships between exogenous nitrogen excretion ( $\mathrm{mg} \mathrm{N} \mathrm{g} \mathrm{g}^{-1} \mathrm{DBM}$ ) and (a) ingested and (b) absorbed nitrogen ration ( $\mathrm{mg} \mathrm{N} \mathrm{g} \mathrm{g}^{-1} \mathrm{DBM}$ ) for Sardinops sagax fed on phytoplankton and zooplankton diets. Data from experiments in which phytoplankton was used as food are indicated by an open circle (o) and those from experiments with zooplankton are indicated by a closed circle $(\bullet)$. Linear regressions are fitted to the data

These regressions indicate that $69.8 \pm 11.1 \%$ of the nitrogen in the ingested ration and $74.4 \pm 12.1 \%$ of the nitrogen in the assimilated ration was excreted. In conjunction with the estimated daily endogenous nitrogen excretion rate $\left(0.028 \times 24=0.675 \mathrm{mg} \mathrm{N} \mathrm{g}^{-1} \mathrm{DBM} \mathrm{d}^{-1}\right)$, and assuming that nitrogen not excreted is retained such that:

$$
r_{\mathrm{N}}=R_{\mathrm{N}}-e_{\mathrm{N}}
$$

where $r_{\mathrm{N}}$ is retained nitrogen ( $\mathrm{mg} \mathrm{N} \mathrm{g}^{-1} \mathrm{DBM}$ ), Eqs. (3) \& (4) may be used to estimate the daily maintenance ration (i.e. zero net growth) required by sardine. Rearranging Eq. (3) gives:

$$
r_{N}=0.302 R_{N}
$$

where $r_{\mathrm{N}}$ is nitrogen retained by the fish $\left(\mathrm{mg} \mathrm{N}^{-1}\right.$ DBM). For zero net growth during $1 \mathrm{~d}$, sufficient nitrogen must be ingested to supply that which is excreted endogenously, i.e.

$$
0.302 R_{d}=0.675
$$

SO:

$$
R_{\mathrm{d}}=(0.675 / 0.302)=2.24 \mathrm{mg} \mathrm{N} \mathrm{g}^{-1} \mathrm{DBM} \mathrm{d}^{-1}
$$

where $R_{d}$ is the ingested daily maintenance ration. Similarly, absorbed daily maintenance ration can be estimated:

$$
p R_{\mathrm{d}}=(0.675 / 0.256)=2.64 \mathrm{mg} \mathrm{N} \mathrm{g}^{-1} \mathrm{DBM} \mathrm{d}^{-1}
$$

For zero net growth, i.e. no gain or loss in nitrogen, sardine require an ingested ration of $2.24 \mathrm{mg} \mathrm{N} \mathrm{g}^{-1}$
DBM d $\mathrm{d}^{-1}$, equivalent to $2.11 \%$ of their body nitrogen per day, and an absorbed ration of $2.64 \mathrm{mg} \mathrm{N} \mathrm{g}^{-1} \mathrm{DBM}$ $\mathrm{d}^{-1}$, equivalent to $2.48 \%$ of their body nitrogen per day.

\section{Faeces elimination}

Sardine faeces were cohesive, robust and easy to collect. Faeces from fish fed phytoplankton were browngreen in colour, whereas those from fish fed zooplankton were red-brown. For fish fed phytoplankton, faecal elimination rates increased from an initial low rate to a peak 5.0 to 17.0 (mean $=8.9 \pm 5.5$ ) h after the midpoint of feeding (Fig. 1). Peak faecal elimination rates for fish fed phytoplankton ranged from 0.11 to $0.35 \mathrm{mg} \mathrm{g}^{-1} \mathrm{DBM} \mathrm{h}^{-1}$, and elimination rates declined exponentially from peak values for 12 to $25 \mathrm{~h}$, after which they continued at a low ( 0.01 to $0.02 \mathrm{mg} \mathrm{g}^{-1} \mathrm{DBM} \mathrm{h}^{-1}$ ), constant rate for the duration of the experiment (Fig. 1). For fish fed zooplankton, faecal elimination rates were much lower, were less variable, and increased more rapidly from initial low rates to peak levels. Peak faecal elimination rates for fish fed zooplankton occurred 3.5 to 7.0 (mean $=6.2 \pm 2.0) \mathrm{h}$ after the midpoint of feeding (Fig. 2), and ranged from 0.06 to $0.08 \mathrm{mg} \mathrm{g}^{-1} \mathrm{DBM} \mathrm{h}^{-1}$. An exponential decline from peak rates was evident for 27.5 to $37 \mathrm{~h}$, after which faeces continued to be eliminated at a low 10.005 to 0.02 $\mathrm{mg} \mathrm{g}^{-1} \mathrm{DBM} \mathrm{h}^{-1}$ ) rate for the rest of the experiment.

The coefficient of the exponential decline in faecal elimination rates was estimated by regressing the natural $\log$ of faeces elimination rate against time over the period of exponential decline. Significant $(p<0.01)$ linear regressions were obtained for all experiments. The period of exponential decline was much shorter for fish fed phytoplankton (mean $=16.5 \pm 5.8 \mathrm{~h}$ ) than for those fed zooplankton (mean $=32.8 \pm 3.6 \mathrm{~h}$ ), and the coefficients of the exponential decline in faecal elimination

Table 2. Sardinops sagax. Regression parameters including sample size, $\mathrm{r}^{2}$ value, significance level and slope value \pm 1 standard error ( $\mathrm{C}: \mathrm{N}$ ratio $\mathrm{h}^{-1}$ ) for the equations relating faecal $\mathrm{C}: \mathrm{N}$ ratios to time for sardine fed phytoplankton and zooplankton diets. NS indicates not significant

\begin{tabular}{|lcrrcc|}
\hline Food type & Expt & $\mathrm{n}$ & $\mathrm{r}^{2}$ & $\mathrm{p}$ & Slope \\
\hline Zooplankton & LA 4A & 20 & 0.63 & 0.001 & $0.221 \pm 0.038$ \\
Zooplankton & LA 7A & 26 & 0.32 & 0.005 & $0.046 \pm 0.013$ \\
Zooplankton & LA 7B & 26 & 0.53 & 0.001 & $0.068 \pm 0.013$ \\
Zooplankton & LA 9A & 22 & -0.05 & NS & - \\
Zooplankton & LA 9B & 22 & -0.04 & NS & - \\
Zooplankton & SA 2B & 18 & 0.39 & 0.005 & $0.033 \pm 0.009$ \\
Phytoplankton SA 2A & 20 & -0.03 & NS & - \\
Phytoplankton SA 3A & 21 & 0.36 & 0.005 & $-0.025 \pm 0.007$ \\
Phytoplankton SA 3B & 21 & 0.35 & 0.005 & $-0.036 \pm 0.011$ \\
Phytoplankton SA 5B & 25 & 0.48 & 0.001 & $-0.044 \pm 0.009$ \\
\hline
\end{tabular}




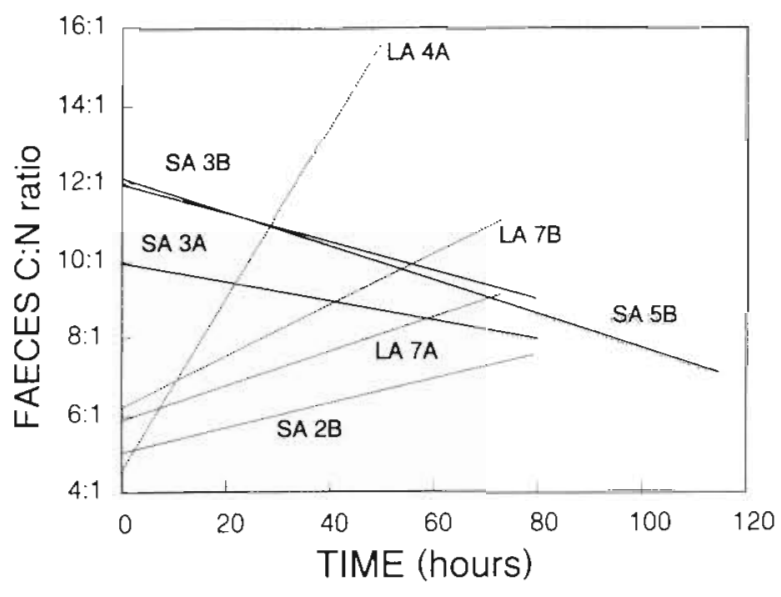

Fig. 5. Linear regressions of faeces $C: N$ ratio as a function of time for experiments where a significant relationship was found between these 2 variables (see Table 2). Regressions from experiments in which phytoplankton was used as food are indicated by a solid line and those from experiments with zooplankton are indicated by a dotted line

rates were higher and were more variable for fish fed phytoplankton (mean $\left.=-0.105 \pm 0.043 \mathrm{~h}^{-1}\right)$ compared to those fed zooplankton (mean $=-0.048 \pm 0.013 \mathrm{~h}^{-1}$ ).

Elimination of the meal was much slower than the excretion of dissolved nitrogen from the ration for fish fed either zooplankton or phytoplankton. Despite the difference in faecal elimination rates between fish fed different diets, food type had no effect on the time required to eliminate 50 and $90 \%$ of the faeces produced; the mean time to $50 \%$ elimination was $13.0 \pm 4.1 \mathrm{~h}$, and that required for $90 \%$ elimination was $50.8 \pm 8.3 \mathrm{~h}$.

Despite some variability in the faeces $C: N$ ratio data (Figs. 1 \& 2), significant trends in this ratio over time were observed in 7 of the 10 experiments conducted (Table 2). In 3 of the 4 experiments in which fish were fed phytoplankton, the faeces $\mathrm{C}$ : N ratio showed a similar and significant decrease over the duration of the experiment (Fig. 1. Table 2), declining from a ratio of approximately $11: 1$ to $9: 1$. The single phytoplankton experiment during which the $\mathrm{C}: \mathrm{N}$ ratio did not change over time was that where Melosira spp. was used as the food organism. This decline in C: $\mathrm{N}$ ratios over time indicates that either the efficiency of carbon absorption from the faeces increased, or the efficiency of nitrogen absorption decreased. In contrast, the faeces $C: N$ ratios for fish fed zooplankton significantly increased over the duration of the experiment in 4 of the 6 experiments (Fig. 2, Table 2). For 3 of these experiments the regressions were similar, increasing from 5:1 to 9:1 (Fig. 5). In the case of experiment LA 4A, the C:N ratio increased markedly to $15: 1$. This increase in the $\mathrm{C}$ : N ratio during the experiment suggests that either the efficiency of nitrogen absorption increased, or the efficiency of carbon absorption decreased, over this time period.

\section{Absorption efficiencies}

Overall dry mass, carbon and nitrogen absorption efficiencies for sardine fed phytoplankton and zooplankton were calculated using Eq. (1). In all experiments nitrogen absorption efficiencies exceeded those for carbon, and both were higher than the dry mass absorption efficiencies (Table 3). There was little variation in the dry mass and carbon absorption efficiencies for experiments during which the fish were fed phytoplankton. However, a low nitrogen absorption efficiency of $60.1 \%$ was calculated when Melosira spp. was the food source, compared to values ranging from 75.2 to $83.2 \%$ when planktonic diatoms were used as food. Because Melosira spp. is a tachypelagic genus, being primarily benthic but occasionally found in the plankton (Cupp 1943), and rare in southern African waters (Taylor 1964), it is unlikely to form part of the sardine's diet in the field. Absorption efficiency data for sardine fed this diatom were therefore not included when estimating mean absorption efficiencies. Mean absorption efficiencies of fish fed pelagic diatoms were $42.6,62.6$ and $78.7 \%$ for dry mass, carbon and nitrogen respectively (Table 3 ).

Absorption efficiencies for sardine fed zooplankton also showed little variation, with the exception of the dry mass absorption efficiency estimated for experiment LA 9B (Table 3). Mean absorption efficiencies of fish fed zooplankton were 77.6, 88.2 and $93.3 \%$ for dry mass, carbon and nitrogen respectively (Table 3 ). The mean dry mass, carbon and nitrogen absorption efficiencies were significantly higher for sardine fed zooplankton than for those fed phytoplankton ( $t_{\text {drymass }}=$ $8.43, p<0.001 ; t_{\text {carbon }}=6.83, p<0.01 ; t_{\text {nitrogen }}=5.81, p<$ $0.05)$.

Table 3. Sardinops sagax. Dry mass, carbon and nitrogen absorption efficiencies $(\%)$ of sardine fed zooplankton and phytoplankton diets. Mean absorption efficiencies $1 \pm 1$ standard deviation) for phytoplankton and zooplankton are given

\begin{tabular}{|lcccc|}
\hline Expt & Food type & Drymass & Carbon & Nitrogen \\
& & & & \\
\hline LA 4A & Zooplankton & 76.7 & 90.0 & 92.0 \\
LA 7A & Zooplankton & 83.9 & 89.8 & 94.3 \\
LA 7B & Zooplankton & 86.3 & 93.0 & 96.6 \\
LA 9A & Zooplankton & 80.4 & 88.9 & 93.4 \\
LA 9B & Zooplankton & 60.9 & 79.3 & 90.8 \\
SA 2B & Zooplankton & 77.4 & 88.4 & 92.4 \\
Average & & $77.6 \pm 9.0$ & $88.2 \pm 4.7$ & $93.3 \pm 2.0$ \\
SA 3A & Phytoplankton & 42.2 & 62.6 & 77.8 \\
SA 3B & Phytoplankton & 39.5 & 68.2 & 83.2 \\
SA 5B & Phytoplankton & 46.2 & 57.0 & 75.2 \\
Average & & $42.6 \pm 3.4$ & $62.6 \pm 5.6$ & $78.7 \pm 4.1$ \\
SA 2A & Algae & 51.3 & 60.1 & 60.1 \\
\hline
\end{tabular}




\section{DISCUSSION}

Like other marine teleosts, Sardinops sagax is predominantly ammoniotelic (Handy \& Poxton 1993), with ammonia constituting $68.6 \%$ of the total nitrogen excreted by unfed fish, and $75.3 \%$ for fish fed on mysids. Endogenous excretion rates determined for sardine (19.28 and $2.46 \mu \mathrm{g} \mathrm{N} \mathrm{g}^{-1} \mathrm{DBM} \mathrm{h}^{-1}$ for ammonia- $\mathrm{N}$ and urea- $\mathrm{N}$ respectively) are comparable to those of other clupeoids (McCarthy \& Whitledge 1972, Durbin \& Durbin 1981, James et al. 1989a). The endogenous ammonia excretion rate for sardine lies between those of menhaden and Cape anchovy, species for which excretion rates were determined using similar methodology to that employed in this study and between which comparisons are therefore valid. Menhaden are large (101 g DBM), sardine are mediumsized (33 g DBM) and Cape anchovy are small (3 g DBM), and the decrease in endogenous ammonia excretion rates with increasing size across this group of clupeoids most probably reflects a size-specific decline in metabolic rate.

Neither temperature nor fish size affected endogenous excretion rates of Sardinops sagax in this study, although small fish have faster excretion rates than large fish and excretion rates increase with temperature (Handy \& Poxton 1993, Jobling 1994). It may be that the size difference between the 2 experimental groups of fish used here was too small to produce a notable size-related effect, but the lack of a significant increase in ammonia excretion rate over a $7^{\circ} \mathrm{C}$ range is surprising. This may imply a high degree of eurythermy by sardine, as has been previously indicated by the relatively low oxygen consumption $Q_{10}$ value of 1.82 over 10 to $22^{\circ} \mathrm{C}$ for this species (van der Lingen 1995).

The elevation of nitrogen excretion rates shortly after feeding has been reported for several fish species (Brett \& Zala 1975, Savitz et al. 1977, Davenport \& Sayer 1986, Sayer 1988, Du Preez \& Cockroft 1988a, b, Handy \& Poxton 1993, Jobling 1994). For Sardinops sagax, ammonia excretion rates after feeding on phytoplankton were 3.5 times endogenous levels, whereas rates of fish fed zooplankton were almost 10 times endogenous levels. James et al. (1989a) reported elevated ammonia excretion rates of up to $600 \mu \mathrm{g} \mathrm{N} \mathrm{g}^{-1}$ DBM $\mathrm{h}^{-1}$ for Cape anchovy fed on zooplankton, a 25 fold increase from endogenous levels, and Durbin \& Durbin (1981) reported elevated ammonia excretion rates of $120 \mu \mathrm{g} \mathrm{N} \mathrm{g}^{-1} \mathrm{DBM} \mathrm{h}^{-1}$ for Atlantic menhaden fed on phytoplankton, a 16-fold increase from endogenous levels. The significant linear relationship between peak nitrogen excretion rate and nitrogen ration observed here for sardine has previously been reported by Jobling (1981) for young plaice Pleu- ronectes platessa, and also by Ramnarine et al. (1987) for juvenile Atlantic cod Gadus morhua. Since the physiological mechanisms governing nitrogen excretion are likely to have a maximum capability, it has been suggested that an asymptotic relationship would best describe this relationship (Jobling 1981, Ramnarine et al. 1987). The linear relationship reported here for sardine would suggest that ration sizes used were too small to reach asymptotic levels in nitrogen excretion.

Sardine excreted a constant proportion of nitrogen from the ingested $(69.8 \pm 11.1 \%)$ and absorbed $(74.4 \pm$ $12.1 \%$ ) rations. Similar relationships have been reported for other fish species (Gerking 1971, Savitz et al. 1977. Weisberg \& Lotrich 1982), and for the other clupeoids studied (Durbin \& Durbin 1981, James et al. 1989a). Atlantic menhaden also excreted more than half of their ingested and absorbed rations (61.6\% and $65.5 \%$ respectively; Durbin \& Durbin 1981), whereas Cape anchovy were more efficient at retaining nitrogen, and excreted only $41.5 \%$ of the ingested and $47.8 \%$ of the absorbed ration (James et al. 1989a). The absorbed daily maintenance ration of $2.64 \mathrm{mg} \mathrm{N} \mathrm{g}^{-1}$ $D B M d^{-1}$ required by sardine is higher than that estimated for either Atlantic menhaden or Cape anchovy (0.70 and $2.17 \mathrm{mg} \mathrm{N} \mathrm{g}^{-1}$ DBM d $\mathrm{d}^{-1}$ respectively), and appears to contradict the endogenous excretion data which reflected a decreasing metabolic rate with increasing size. However, this difference may be a result of the poor estimation of the slope of the regression between exogenous excretion and ration determined in this study.

Faecal elimination rates of sardine were affected by food type. Rates were higher but declined more rapidly for fish fed phytoplankton, whereas the lower elimination rates for fish fed zooplankton declined over a longer period of time. The times to 50 and $90 \%$ faeces elimination were not affected by either food type or ration size. Peak faecal elimination rates for sardine (0.06 to $0.35 \mathrm{mg} \mathrm{g}^{-1} \mathrm{DBM} \mathrm{h}^{-1}$ ) are lower than those reported for either Atlantic menhaden $(0.7$ to $2.0 \mathrm{mg}$ $\mathrm{g}^{-1} \mathrm{DBM} \mathrm{h}^{-1}$; Durbin \& Durbin 1981) or Cape anchovy (0.2 to $1.4 \mathrm{mg} \mathrm{g}^{-1} \mathrm{DBM} \mathrm{h}^{-1}$; James et al. 1989a), and are likely to be a result of small ration size. The faecal elimination results reported here corroborate previous work which indicated that phytoplankton is evacuated by sardine much faster than zooplankton (van der Lingen 1998).

The effect of food type on faeces $\mathrm{C}: \mathrm{N}$ ratios observed here, with faeces from sardine fed phytoplankton showing a declining trend during the course of an experiment whereas those from fish fed zooplankton showed an increasing trend, has not been reparted elsewhere. James et al. (1989a) reported that the C:N ratios of Cape anchovy faeces declined during most 
experiments, and did not note any food type effect. By contrast, Harris (1991) found that the C:N ratios of faeces from white steenbras Lithognathus lithognathus fed a formulated diet increased during the course of an experiment. Faeces $\mathrm{C}: \mathrm{N}$ ratios were higher than those of the corresponding food C:N ratios for Atlantic menhaden fed on either phytoplankton or zooplankton (Durbin \& Durbin 1981), although these authors gave no information concerning whether $\mathrm{C}: \mathrm{N}$ ratios changed during the experiment. Because the ash content of faeces was not measured in the present study, changes in the absorption efficiency of carbon and nitrogen during the course of an experiment could not be measured as was done by Durbin \& Durbin (1981) and James et al. (1989a). However, a declining $C: N$ ratio over time indicates a decrease in the efficiency of nitrogen absorption, whereas an increasing ratio indicates an increase in the efficiency of nitrogen absorption.

Sardine have higher absorption efficiencies for nitrogen than for carbon regardless of food type, a response shared by Cape anchovy and Atlantic menhaden. Sardine also absorb both elements more efficiently from zooplankton than from phytoplankton. Food type has no effect on nitrogen or carbon absorption by menhaden, but anchovy fed phytoplankton have similar nitrogen but lower carbon absorption efficiencies than those fed zooplankton (Table 4). No significant ( $p<$ 0.05) differences were observed between zooplankton-derived carbon and nitrogen absorption efficiencies of sardine, anchovy and menhaden (Kruskal-Wallace analysis of variance by ranks [Zar 1984]; Table 4), whereas significant differences were observed for phytoplankton-derived carbon and nitrogen absorption efficiencies between species. When fed phytoplankton, menhaden had higher carbon and nitrogen absorption efficiencies than sardine or anchovy, whereas sardine and anchovy showed similar absorption efficiencies on this diet. Because of the small size of the data sets however, a rigorous statistical analysis could not be performed, and observations regarding the relative absorption efficiency of these species should be regarded as tentative.

That menhaden appear to be the most efficient species at utilizing phytoplankton seems reasonable, because this species is an obligate filter-feeder which consumes substantial quantities of phytoplankton and is able to retain particles of 13 to $16 \mu \mathrm{m}$ (Durbin \& Durbin 1975). The absorption efficiency data presented here would imply that sardine are a primarily carnivorous species, as they have higher absorption efficiencies for both carbon and nitrogen when fed zooplankton compared to phytoplankton. Whereas crustacean zooplankton do form a significant component of the sardine's diet both locally (Davies 1957 , King \& Macleod 1976, van der Lingen 1996) and globally (Hand \& Berner 1959, Alamo \& Bouchon 1987), substantial quantities of phytoplankton in the stomach of this species have also been recorded by those authors. Sardine are thus clearly omnivorous, and the relative dietary importance of phytoplankton and zooplankton is likely to vary both spatially and temporally. Compared to Cape anchovy, which cannot capture food particles smaller than $200 \mu \mathrm{m}$ (James \& Findlay 1989), sardine can entrap particles of down to $17 \mu \mathrm{m}$ (van der Lingen 1994), and are therefore better able to utilize phytoplankton blooms when they encounter them. Although both species have similar absorption efficiencies for phytoplankton, this difference in small particle capture efficiency means that phytoplankton are likely to be more significant in the diet of sardine than in that of Cape anchovy.

The results reported here will be used to construct carbon and nitrogen budgets for Sardinops sagax, as has been done using similar methodology for Cape anchovy (James et al. 1989b) and Atlantic menhaden (Durbin \& Durbin 1983). The development of such experimentally derived budgets can provide valuable insights regarding the trophic position of sardine in the southern Benguela upwelling system, and will permit a quantification of how changes in the fish's trophic environment impact upon growth.

Acknowledgements. I thank the Director of the Sea Fisheries Research Institute. Dr A. I. L. Payne, for funds and facilities for this research. Anastasia Polito and Envor Malan are warmly thanked for their extensive assistance during experiments, as is Dr Trevor Probyn for his advice concerning the biochemical analyses. I am extremely grateful to Dr Pat Garratt and Simon Chater of the Two Oceans Aquarium for allowing me to use their display fish as experimental subjects. Drs Larry Hutchings and Coleen Moloney, and 4 anonymous referees are thanked for their comments on the manuscript. 


\section{LITERATURE CITED}

Alamo AV, Bouch on M (1987) Changes in the food and feeding of the sardine (Sardinops sagax sagax) during the years 1980-1984 off the Peruvian coast. J Geophys Res 92 (C13): 14411-14.415

Brett JR, Zala CA (1975) Daily pattern of nitrogen excretion and oxygen consumption of sockeye salmon (Oncorhynchus nerka) under controlled conditions. J Fish Res Bd Can 32:2479-2486

Cupp EE (194.3) Marine plankton diatoms of the west coast of North America. Bull Scripps Inst Oceanogr 5:1-238

Davenport J, Sayer MDJ (1986) Ammonia and urea excretion in the amptibious teleost Blennius pholis (L.) in seawater and in air. Comp Biochem Physiol 84A:189-194

Davies DH (195\%) The South African pilchard (Sardinops ocellata). Preliminary report on feeding off the west coast. 1953-56. Investl Rep Div Fish S Afr 30:1-40

Du Preez HH, Cuckroft AC (1988a) Nonfaecal and faecal losses of Pomádasys commersonni (Teleostei: Pomadasyidae) feeding on the surf clam., Donax serra. Comp Biochem Physiol 90A:63-70

Du Preez HH, Cockroft AC (1988b) Nonfaecal and faecal losses of the marine teleost, Lichia amia (Linneaus, 1758), feeding on live southern mullet, Liza richardsoni (Smith. 1846). Comp Biochem Physiol 90A:71-77

Durbin AG, Durbin EG (1975) Grazing rates of the Atlantic menhaden Brevoortia tyrannus as a function of particle size and concentration. Mar Biol 33:265-277

Durbin EG, Durbin AG (1981) Assimilation efficiency and nitrogen excretion of a filter-feeding planktivore, the Atlantic menhaden, Brevoortia tyrannus (Pisces: Clupeidae). Fish Bull US 79:601-616

Durbin EG, Durbin AG (1983) Energy and nitrogen budgets for the Atlantic menhaden, Brevoortia tyrannus (Pisces: Clupeidae), a filter-feeding planktivore. Fish Bull US 81: $177-199$

FAO (1997) The state of world fisheries and aquaculture 1996. FAO Fisheries Department, Rome

Gerking SD (1971) Influence of rate of feeding and body weight on protein metabolism of bluegill sunfish. Physiol Zool 44:9-19

Hand CH, Berner L Jr (1959) Food of the Pacific sardine (Sardinops caerulea). Fish Bull Fish Wildl Serv US 60(164): $175-184$

Handy RD, Poxton MG (1993) Nitrogen pollution in mariculture: toxicity and excretion of nitrogenous compounds by marine fish. Rev Fish Biol Fish 3:205-241

Harris SA (1991) Bioenergetics and growth of white steenbras, Lithognathus lithognathus, under culture conditions MSc thesis, University of Cape Town

James AG (1987) Feeding ecology, diet and field-based studies on feeding selectivity of the Cape anchovy Engraulis capensis Gilchrist. S Afr J Mar Sci 5:673-692

James AG (1988) Are clupeid microphagists herbivorous or omnivorous? A review of the diets of some commercially important clupeids. S Afr J Mar Sci 7:161-177

James AG. Findlay KP (1989) Effect of particle size and concentration on feeding behaviour, feeding selectivity and rates of food ingestion by the Cape anchovy Engraulis capensis. Mar Ecol Prog Ser 50:275-294

James AG, Probyn T, Seiderer LJ (1989a) Nitrogen excretion and absorption efficiencies of the Cape anchovy Engraulis capensis Gilchrist fed upon a variety of plankton diets. J Exp Mar Biol Ecol 131:101-124

James AG, Probyn T, Hutchings L (1989b) Laboratory- derived carbon and nitrogen budgets for the omnivorous planktivore Engraulis capensis Gilchrist. J Exp Mar Biol Ecol 131:125-145

Jobling $M$ (1981) Some effects of temperature, feeding and body weight on nitrogenous excretion in young plaice, Pleuronectes platessa. L. J Fish Biol 18:87-96

Jobling M (1994) Fish bioenergetics. Fish and fisheries series 13. Chapman and Hall, London

King DPF, Macleod PR (1976) Comparison of the food and filtering mechanism of sardine Sardinops ocellata and anchovy Engraulis capensis off South West Africa, 1971-1972. Invest Rep Sea Fish Brch S Afr 111:1-29

Koroleff $F$ (1983) Determination of nutrients. In: Grasshof $K$. Ehrhardt M, Kremling K (eds) Methods of seawater analysis, 2nd edn. Verlag Chemie, Weinheim, p 125-187

Koslow JA (1981) Feeding selectivity of schools of northern anchovy, Engraulis mordax, in the southern California Bight. Fish Bull US 79:131-142

McCarthy JJ, Whitledge TE (1972) Nitrogen excretion by anchovy (Engraulis mordax and E. ringens) and jack mackerel (Trachurus symmetricus). Fish Bull US 70: $395-401$

Nydahl F (1978) On the peroxodisulphate oxidation of total nitrogen in waters to nitrate. Water Res 12:1123-1130

Ramnarine IW, Pirie JM, Johnstone ADF, Smith GW (1987) The influence of ration size and feeding frequency on ammonia excretion by juvenile Atlantic cod, Gadus morhua L. J Fish Biol 31:545-559

Ryther JH (1969) Photosynthesis and fish production in the sea. Science 166(3091):72-76

Savitz J, Albanese MJ, Evinger MJ, Kolasinski P (1977) Effect of ration level on nitrogen excretion, nitrogen retention and efficiency of nitrogen utilization for growth in largemouth bass (Micropterus salmoides). J Fish Biol 11: $185-192$

Sayer MDJ (1988) An investigation of the pattern of nitrogen excretion in Blennius pholis (L.). Comp Biochem Physiol 89A:359-363

Taylor FJR (1964) A study of the phytoplankton of the south western Indian Ocean. PhD thesis, Universily of Cape Town

van der Lingen CD (1994) Effect of particle size and concentration on the feeding behaviour of adult sardine Sardinops sagax. Mar Ecol Prog Ser 109:1-13

van der Lingen CD (1995) Respiration rate of adult sardine Sardinops sagax in relation to temperature, voluntary swimming speed and feeding behaviour. Mar Ecol Prog Ser 129:41-54

van der Lingen CD (1996) Feeding ecology of adult sardine Sardinops sagax. In: Barange $M$, van der Lingen CD (eds) Proceedings and Recommendations of WOSAS - Workshop on Southern African Sardine. Benguela Ecology Programme Report, Cape Town. 29:44-47

van der Lingen CD (1998) Gastric evacuation, feeding periodicity and daily ration of sardine Sardinops sagax in the Southern Benguela upwelling ecosystem. In: Pillar SC. Moloney CL, Payne AIL, Shillington FA (eds) Benguela dynamics. Impacts of variability on shelf-sed environments and their living resources. S Afr J Mar Sci 19: 305-316

Weisberg SB, Lotrich VA (1982) Ingestion, egestion, excretion, growth, and conversion efficiency for the mummichog, Fundulus heteroclitus (L.). J Exp Mar Biol Ecol 62: $237-249$

Zar JH (1984) Biostatistical analysis, 2nd edn. Prentice-Hall, Englewood Cliffs, NJ

Submitted: April 21, 1998; Accepted: September 9, 1998 Proofs received from author(s): December 11, 1998 